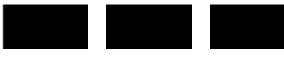 \\ $\square \square$ \\ THE WILLIAM DAVIDSON INSTITUTE \\ AT THE UNIVERSITY OF MICHIGAN
}

\section{The MNC as an Agent of Change for Host-Country Institutions: FDI and Corruption}

\author{
By: Chuck Kwok \& Solomon Tadesse
}

William Davidson Institute Working Paper Number 882

September 2006 


\title{
The MNC as an Agent of Change for Host-Country Institutions: FDI and Corruption
}

\author{
Chuck Kwok + and Solomon Tadesse ++
}

This version: Sept. 2006

\begin{abstract}
Most empirical research examines how the institutional environment of corruption shapes the behavior of MNCs. In this study, we would like to highlight the other side of the picture: how the presence of MNC may shape the institutional environment of corruption over time. We propose three avenues through which the MNC may have an impact on its host institutions: the regulatory pressure effect, the demonstration effect, and the professionalization effect. Based on extensive data on FDI and corruption for a large sample of countries over the last 30 years, the empirical results are consistent with our general hypothesis that foreign direct investment generates positive spillover effects on the institutional environment of host countries. Such findings provide a glimmer of hope for the future of the host country where corruption is most prevalent.
\end{abstract}

Key Words: Foreign Direct Investment, Corruption

JEL Codes: F21, F23, M14, M16, O73

+ Moore School of Business, University of South Carolina, Columbia, SC 29208. E-mail:

ckwok@moore.sc.edu.

++ Corresponding author. Stephen M. Ross School of Business, University of Michigan, Ann Arbor, MI 48109. E-mail: stadesse@umich.edu.

The authors would like to thank participants and the editors of the JIBS Special Issue on the "Three Lens" conference for comments and valuable suggestions. 


\section{Introduction}

With the expansion of international business activities, the study of corruption and its effects has received increased attention recently. Multinational corporations (MNCs) are careful in choosing host countries for their foreign subsidiaries, as they are concerned that pervasive corruption could increase their operational costs and risks. So are also multinational banks, since corruption could drain the investment funds of a country, hampering its economic growth and debt service capacity. International development agencies are concerned that financial aids meant to help economic development and the poor may be squandered by corrupt government officials.

Following Macrae (1982), in this study, we define corruption as an arrangement that involves an exchange between two parties (the "demander" and the "supplier") which i) has an influence on the allocation of resources either immediately or in the future; and ii) involves the use or abuse of public or collective responsibility for private ends. The harmful effects of corruption have been extensively documented in the literature (see, e.g., Mauro (1995, 1997), and Rose-Ackerman (1975)). Corrupt payments amount to a significant percentage of gross national product, since the rents extracted by a corrupt system gets built into the cost structure of organizations. Corruption distorts efficient resource allocation. Corruption rewards unproductive behavior by channeling unmerited contracts and rights to companies in exchange for bribes, at the expense of efficient and innovative firms. The toleration of corruption in some areas of public life can facilitate a downward spiral in which the malfeasance of some encourages more and more people to engage in corruption over time. Pervasive corruption undermines the legitimacy of governments. Corruption in the provision of public goods and services in the imposition of costs casts a cloud over governments seeking popular legitimacy (Rose-Ackerman (1999)).

Most empirical work regarding corruption assumes the context where the institutional setting shapes the behavior of the MNC. We certainly recognize that, in order to strive for external legitimacy, the MNC needs to adapt to its institutional context (Glynn and Abzug (2002)). However, in this study, we would like to point out the other side of the picture: how the presence of MNCs could shape the 
institutional environment of corruption over time. We propose three avenues through which the MNC may have an impact on its host institutions: regulatory pressure effect, demonstration effect, and professionalization effect.

The balance of the paper is organized into five sections. Following the introduction, the second section II reviews the literature on corruption. The third section III explores how the MNC interacts with its host environment and formulates the research hypotheses. In the fourth section, we describe the data and methodology used in the paper. Section V reports the empirical results. Finally, section VI concludes the paper and discusses the implications of our findings.

\section{Literature review}

As a topic of key concern, the study of corruption has generated numerous published scholarly studies. In the academic literature, there are two main streams of studies on the subject. The first stream employs the approach of mathematical modeling to analyze the causes, effects and various conditions related to corruption. For examples, Rose-Ackerman (1975) examines the relationship between market structures and the incidence of corrupt dealings in the government contracting process. She then discusses how revising contracting procedures and reorganizing market structures can reduce criminal incentives of corruption. Shleifer and Vishny (1993) contend that weak governments that do not control their agencies experience high corruption levels. Moreover, the illegality of corruption and the need for secrecy make it much more distortionary and costly than taxation.

The second research stream consists of various empirical studies. This line of research is facilitated by the publication of worldwide corruption indices by agencies such as the Transparency International, World Bank, Economist Intelligence Unit and so forth. The corruption indices can be used either as an independent or dependent variable. For instance, using corruption as an independent variable, studies have found that corruption contributes to suboptimal economic growth (Barro (1996)), poor economic competitiveness (Ades and di Tella (1999)), less investment and inefficient government (Knack 
and Keefer (1995); Mauro (1997)), and a decrease in the level of trust or social capital by citizens (La Porta et al. (1997); Knack and Keefer (1997)).

Using the corruption index as the dependent variable, Husted (1999) finds that corruption is significantly associated with GNP per capita and related to the cultural variables power distance, masculinity and uncertainty avoidance. Robertson and Watson (2004) find that in the short run, the more rapid the rate of change of foreign direct investment (FDI), the higher level of corruption.

\section{MNCs and corruption in host countries}

\section{MNC as an organization shaped by the host institution}

Empirical studies have been conducted to show how a host country's corruption significantly reduces its inflows of foreign direct investment (Lambsdorff (1999); Mauro (1995); Wei (1997)). Besides the volume of FDI inflows, Rodriguez, Uhlenbruck and Eden (2005) contend that the type of corruption in the host country would also affect the choice of entry modes. Using the institutional framework, they introduce a two-dimensional framework of corruption: pervasiveness and arbitrariness. They argue that the higher the pervasiveness of corruption, the higher is the likelihood that an MNC will choose to enter via a wholly owned subsidiary rather than a local partner.

Most of the studies mentioned above examine how the institutional environment of corruption may shape the behavior of MNCs. We certainly recognize that in order to strive for external legitimacy, the MNC needs to adapt to its institutional context (Glynn and Abzug (2002)). However, in this study, we would like to highlight the other side of the picture: how the presence of MNC may shape the institutional environment of corruption over time. We contend that the MNC is not just a passive subject; it may also serve an agent of change. 


\section{MNC as an agent of change to the host institution}

Using the framework of the institutionalization theory, Westney (1993) discusses the potential significant impacts of MNCs on the organizational patterns within a country. MNC subsidiaries in some countries can play a major role in establishing building blocks of organizations. The introduction of new modes of business practice in MNC subsidiaries can challenge the legitimacy of existing patterns and stimulate debates on better business practice in the host country. The mirror image of this influence is the “de-institutionalization” of local firms’ existing organizational patterns. Similarly, Dacin, Ventresca and Beal (1999) review research on organizations to highlight prevailing and emerging conceptions on embeddedness. They briefly discuss the concept of “disembeddedness”. They argue that globalization may be regarded as a disembedding process that strips individuals and firms from their local structures and allows for restructuring at a more global level.

Following this perspective, we contend that the presence of foreign-owned subsidiaries will, on the average, reduce the level of corruption of the host country. We propose that the MNC influences its institutional environment over time via three major effects: regulatory pressure effect, demonstration effect, and professionalization effect. ${ }^{1}$ For better explanation, our main ideas are illustrated in Figure 1. This diagram conveys as a general framework on how the MNC may serve as an agent of change for host-country institutions.

Within the host country environment, local governments and the business community influence the behavior of foreign-owned subsidiaries. In Figure 1, we use a thick arrow line to represent such influence, indicating that such influence tends to be strong and immediate. However, we argue that there is a milder force of influence flowing back from the MNC to the host government and business

1 We benefited much from the insights of DiMaggio and Powell (1983) who discuss institutional isomorphism. Isomorphism is a constraining process that forces one unit in a population to resemble other units that face the similar set of environmental conditions. Our proposed three effects correspond with their three mechanisms of isomorphism: coercive isomorphism; mimetic isomorphism; and normative isomorphism. However, the focus of DiMaggio and Powell is on isomorphism. In order not to confuse readers who are familiar with the institutional theory, we use three other terms to represent the effects through which the MNC may shape the host country institution over time. 
community. We use a thin arrow line to represent such influence as it is mild, subtle and takes long time to realize. Besides conforming to the local business practice to gain legitimacy, MNCs are also accountable to and constrained by their home-country environment and the international business community at large. Through the regulatory pressure, demonstration, and professionalization effects, MNCs gradually shape the host-country institutions. One motivating factor for the host institutions to change is that the host country also wants to gain legitimacy within the bigger, global business environment. As the host country grows, it would like to enhance its international reputation and attracts more business. Under this general framework of how MNCs may shape host-country institutions over time, we study the specific relationship between FDI and host-country corruption.

\section{Regulatory pressure effect}

In a business culture where corruption is pervasive, corruption becomes the modality of business practice in local businesses and government offices. It becomes part of the regular practice and both parties of the transaction would take it for granted. However, when a government official deals with a foreign entity, he or she may not be able to conduct business as usual. The business people representing the MNCs may be reluctant in offering a bribe. Firstly, the subsidiary of an MNC is faced with two sets of isomorphic pressures --- the MNC's and the host country's (Davis et al. (2000); Kostova and Roth (2002)). Besides trying to gain external legitimacy by adopting the common corrupt business practice of the host country, it also has to strive for internal legitimacy as the headquarter in the home-country environment may have adopted norms and practices that ban corrupt behaviors by their subsidiaries.

Secondly, there is the regulatory pressure from the home government and the international business community (DiMaggio and Powell (1983), Oliver (1997)). For instance, the U.S. Foreign Corrupt Practices Act, enacted in 1977, was prompted by a series of scandals involving questionable payments by U.S. firms to overseas government officials. This act prohibits U.S. firms from giving anything of value (such as a payment, gift or bribe) to induce a foreign government to enter into a contract or business advantage or relationship. This act carries criminal penalties, imprisonment for up to five years, fines of up to $\$ 100,000$ for individuals, and fines up to $\$ 2$ million for companies. 
Similar legislation is enacted in the global business community. On November 21, 1997, representatives from 33 countries signed the Convention on Combating Bribery of Foreign Public Officials in International Business Transactions. Among them were 28 of the 29 member states of the Organization for Economic Cooperation and Development (OECD), together with Argentina, Brazil, Bulgaria, Chile, and the Solvak Republic (Doh et al., 2003).

Under regulatory pressure from home country and the international business community, the employees of MNC's subsidiaries are reluctant to offer bribes. If the MNC has enough bargaining power and its presence is much desired by the host government, it may simply refuse offering bribes. Even if the subsidiary employees think that they need to engage in bribery in order to secure business, the local officials may need to think of some circuitous ways to accept the bribes so that the MNC employees are less likely to get caught. Facing a foreign business party, the local government officials are constrained somewhat in their bribery acts. It cannot be just business as usual.

\section{Demonstration effect}

In the international business literature, there is a line of research that studies spillover effects of foreign direct investment (Globerman (1979), Haddad and Harrison (1993), Eden et al. (1997), Aitken and Harrison (1999), and Liu et al. (2000)). The discussion of the spillover effects concentrates mainly on productivity and technological transfer. For instance, Blomström and Kokko (1998) and Gorg and Strobl (2001) summarize how FDI may affect the productivity of domestic firms. First, competition from FDI may force domestic firms to update production technology and change management styles in order to maintain their competitiveness. Second, domestic firms may learn from observing the MNCs' practice when there are close relationships between them. Thirdly, MNCs train their employees who may later move to domestic firms with learnt skills.

Following this line of thought, we argue that there may also be a spillover or demonstration effect on corruption (Oliver (1997)). In some host countries, corruption has been immersed deep in the local business culture. Local business people and government officials may think that this is the "normal" way to get business done. However, when they deal with the MNCs through negotiations, joint ventures, 
upstream or downstream relationships in the business chains, being geographically and operationally proximate, they have opportunities to observe closely how business decisions and allocations are made within the MNCs (Eden et al. (1997)). Business can be conducted more efficiently in an environment built on trust and ethical conduct. In the past, local advocates might also "talk" about ethical business practice but might not produce a concrete, real example to follow. The presence of MNCs demonstrates how a cleaner way of conducting business can be more effective and efficient in the long run. Furthermore, outward-looking local business people and government officials also want to gain legitimacy within the global business community. They want to enhance the country's international reputation and to attract more business. They may model themselves after the MNCs and change their traditional business practices gradually.

\section{Professionalization effect}

DiMaggio and Powell (1983) discuss two important aspects of professionalization. One is the resting of formal education and of legitimation in a cognitive base produced by university specialists. The other is the growth and elaboration of professional networks that span organizations and across which new models diffuse rapidly.

MNCs have been in the forefront of the application of automation, information technology and managerial techniques in order to enhance business efficiency. Alternatively, academicians strive to improve business knowledge and develop practical applications by conducting theoretical and empirical research. All areas of business have, to one degree or another, become sciences. Academic curricula have become increasingly standardized and professionalized. Business schools around the world tend to adopt textbooks and course contents from the same pool of leading authors and universities. In order to excel above their peers, managers want to acquire professional business training. Afraid of being left out by competitors, even family-owned businesses consider sending their "heirs" to business schools (Ramirez and Kwok (2006)).

To the younger generation, the MNCs have special appeal. MNCs usually offer substantially better salaries than domestic companies in host countries. Not only is working for MNCs prestigious, they 
can be exposed to sophisticated management practices, which will equip them with skills for a successful business career in the long run. Furthermore, they may be given opportunities to go overseas for shortterm training or business assignments.

To enhance their chance of being recruited by MNCs, the young generation needs to learn about global business practices. They attend schools to acquire professional business training. To certify their qualifications, they may take public examinations and join professional associations. Such professional organizations may set industry-wide ethical codes of conduct, product quality standards, uniform training or credentialing in occupational professions (Oliver (1997)). Socialized by the professional business values, they become increasingly critical of the traditional ways. As the "new blood" rise in the corporate ladder, they become business leaders. They may work for the MNC, they may have started their own business, or they may have become senior advisors to government officials. They may use their influence to gradually reform the more corrupt old business practices. In short, the professionalization of the management practice and the socialization of the younger generation lead to the changes in the host country institutions over time.

Through the three effects mentioned above, we contend that the presence of MNCs may help reduce corruption in the host country over time. We put forward the following research hypothesis:

H1: $\quad$ The level of foreign direct investment in a host country is negatively related to its level of corruption over time. ${ }^{2}$

However, we need to add quickly that it would be naïve to think that the influence of MNCs on its environmental institution is always good. There are plenty of anecdotal evidences that MNCs sometimes bring undesirable influences. In some situations, MNCs exploit natural resources, cause environmental pollution, employ child labor, or take advantage of the looser regulations of the host countries (to bypass the stringent regulations and costly requirements of parent countries). In fact,

Our hypothesis is on an average effect. First, some MNCs may still engage in corrupt transactions to facilitate their operation. Second, there are also foreign direct investment flows among developed countries where both the home and host countries do not experience a high level of corruption. In that case, the corruption-reduction effect may be minimal. To examine this latter point, in our robustness tests, we exclude OECD countries from our sample of host countries. The findings are generally robust. Owing to space constraint, the tables of these additional findings are not included in this paper but will be made available to readers upon request. 
Robertson and Watson (2004) argue that foreign direct investment will lead to an increase of corruption in the host country in the short run. Firstly, the increase in FDI represents a larger amount of foreign money flowing into country and, therefore, an expansion of opportunities for bribery. Secondly, the eagerness of foreign investors to enter the market may tempt host country nationals to resort to corruption as a means of sharing in the opportunities for profit presented by their own country (Robertson and Watson (2004)). ${ }^{3}$ Thirdly, equipped with advanced knowledge in international business and a vast international network, MNCs may have developed sophisticated skills of bribery. Such practices will "contaminate" firms in the host country. To represent this opposite view, we put forward the following alternative hypothesis:

H1a: $\quad$ The level of foreign direct investment in a host country is positively related to its level of corruption over time.

\section{Data and research methodology}

We attempt to explain the cross-country variations in the extent of corruption based on variations in the degree of past foreign investment penetration in the economy and other known controls. To that end, we construct a database composed of three sets of data: (1) measures of corruption in the 2000s (the dependent variable); (2) measures of MNC presence or foreign direct investment, education, and culture (the independent variables); and (3) other controls. We have data on these sets of variables for up to 140 countries.

\section{The dependent variable: corruption}

Our dependent variable is the extent of corruption in recent years, and is measured by the average of yearly corruption perception indices over the period 2000 through 2004 obtained from Transparency International (TI). The TI Corruption Perception Index provides yearly ranking of countries in terms of the extent of perceived corruption among, primarily, public officials. The index is a composite measure

3 Robertson and Watson (2004) find empirical support for their hypothesis. They use a 1- and 2-year lag-time between the predictor variable (FDI) and the dependent variable (corruption). Their result reflects more on the short-term effect. On the other hand, the focus of this paper is on the long-term effect of FDI on corruption as the suggested three effects take time to realize. 
based on polls and surveys of business leaders, residents and country analysts on their experience of corruption in the respective countries drawn from seven different independent institutions. ${ }^{4}$ Table 1 reports the summary statistics of the variables while Table 2 shows their correlation coefficients. There is a wide cross-country variation in the corruption index, ranging from 0.22 in Finland and 0.44 in Denmark to 8.9 in Bangladesh and 8.66 in Nigeria. Consistent with previous research (e.g., Husted (1999)), wealthier countries tend to be less corrupt. The corruption perception index is significantly negatively correlated with log of per capita GDP.

\section{The main independent variable: FDI}

We measure the presence of MNCs in a host country by the average net Foreign Direct Investment (FDI) inflows as a percentage of GDP. We attempt to explain variations in corruption in the 2000s based on the degree of foreign investment penetration in the past. We expect a significant time lag for the effects to realize but we do not know how far in the past the FDI should be in explaining current variations in corruption. Nonetheless, we have available data on FDI inflows from 1970 through 1997. Thus, we consider decade averages of FDI per GDP in the 1970s, the 1980s and the 1990s, as well as an average over the period 1970 through 1997 respectively. The data on FDI inflows and GDP is obtained from the World Development Database maintained by the World Bank.

Table 1 provides a summary of the decade averages of FDI to GDP ratios for the sample. The flow of FDI shows an increasing trend, the average growing from 0.93 percent of GDP in 1970s to 1.089 percent in the 1980s and 2.128 percent in the 90s. In general, high level of FDI appears to be associated with low corruption in the 2000s. The correlation coefficients between FDI and corruption are mostly negative and significant (see Table 2).

4 The corruption perception index is a continuous scale variable, taking values from 0 to 10 . The higher the value, the less corrupt the country is. To make the scaling more intuitive, we rescale the corruption perception index by deducting it from 10, so that a 0 on the new scale signifies a corruption-free country and a 10 represents an absolutely corrupt country. 


\section{Empirical findings}

\section{FDI and corruption}

To explore the relations between corruption and the extent of past FDI while controlling for other potential country factors, we estimate multivariate empirical models. Table 3 presents the main results of the multivariate regression of corruption on FDI, controlling for a host of control variables. The model is of the form:

$$
\operatorname{CORRUPTION}_{C}=\alpha+\beta^{*} \mathrm{FDI}_{C}{ }^{70 s, 80 s, 90 s, 0 r 1970-1997}+\sum_{i=1}^{n} \lambda^{i} Z^{i}{ }_{C}+\varepsilon_{c},
$$

where FDI is the FDI inflows as a fraction of GDP, and Z is a set of country-specific control variables representing the macro-economic, political, legal, religious orientation and institutional environments of countries that potentially explain the cross-country variations in corruption. FDI $_{C}$ will alternatively take the values of decade averages of FDI in 1970s, in 1980s, in 1990s and the average FDI to GDP ratio over 1970 through 1997, whereas CORRUPTION will take the average per country of the yearly Corruption Perception Index averaged over the period 2000 through 2004.

Table 3 clearly shows that past FDI inflows explains a significant portion of the cross-country variations in corruption. Columns I through IV include the decade averages of FDI to GDP ratios in combination with the level of GDP per capita as a measure of wealth in the regression. The results show that the prevalence of corruption today is, on average, lower in countries with larger foreign direct investment in the past, regardless of how far back we measure the FDI. The coefficients on the key variables of interest, FDI in 1970s, 1980s, 1990s and 1970 through 1997, are robustly negative and statistically significant at the one per cent level. The result is broadly consistent with and suggestive of our hypothesis. Consistent with earlier studies (e.g., Husted (1999) and Mauro (1995)), wealthier countries have less prevalence of corruption. In general the model works well; in this large sample of 87 to 100 countries, the model explains up to 79 percent of the cross-country variation in the prevalence of current corruption. To strengthen the veracity of the findings, we control for other variables suggested in 
the literature, which may also influence a country's propensity to corruption. We group these controls into three categories: 1) Education/Human Capital; 2) Political Tradition; and 3) Legal Environments.

\section{Control for education/human capital}

The benefits of education as an institution to economic welfare have been well documented. Education explains cross-country differences in economic growth across countries (see, e.g., Barro (1991). Education opens up peoples' eyes to new ways of thinking and practice, and is a source of increased productivity, efficiency and growth. The development of a critical mass of educated class would have the potential to change the old ways of life, including corruption. In some way, the effects of education are similar to those of FDI; much of the benefits are not immediate. To control for the impacts of education, we include decade averages of secondary school enrollment (as a percentage of eligible population of the age group) from the World Development database. Columns (V) through (VIII) of Table 3 show that the effect of educational investment on corruption is similar, though weak, as that of FDI.

\section{Control for political tradition}

The political tradition of the country has a significant impact on its institutional environment. Governments differ in their role as facilitators of institutional change, and the effect they have on business practices (see, e.g., Rao et al. (2005)). Autocratic political cultures that lack transparency where political actors are prone to undermine the rule of law tend to be a breeding ground for abuse of public office, including corruption. In contrast, open societies with democratic political culture and appropriate checks and balances in place for constraining actions of political actors are less prone to such abuse. To control for the effects of political traditions, we use two variables: a measure of the extent of democratic political system in the country (Jaggers and Marshall (2000)) and a measure of constraints on political actors in the system (Henisz (2000)). The two variables have significant correlation. To reduce the possibility of multicollinearity from inclusion of both in the same regression, we orthogonalize the democracy variable on political constraint and include only the residual value of political constraint. Columns IX through XII report that the marginal effect of political traditions is not as significant, once 
one controls for wealth, FDI and education. More democratic countries tend to be less corrupt on average, though the result is weak and is not sustainable in all specifications.

\section{Control for legal environment}

A weak legal system where basic rule of law is lacking would be permissive of abuse of public office through its failure of legally constraining those in power. In addition, even in the presence of basic rule of law, the substantive and procedural contents of the law could be a source of variation in the efficiency of the legal system. Legal systems that are cumbersome in procedural formalism and short of the legal flexibility that are needed for judicial actions tend to increase the costs of legal proceedings, prompting the public to seek extra-judicial means of resolution, including corruption. We include the 'rule of law’ and the 'legal formalism’ variables developed by Djankov et al. (2003) in our regressions. Consistent with our conjecture, columns (XIII) through (XV) show that countries with the prevalence of rule of law tend to be less prone to corruption. Legal systems that are more formal and less flexible appear to be associated with higher corruption.

As seen in the regression results in Table 3, our main finding that increased past FDI reduced the prevalence of current corruption is robust to the inclusion of controls for the legal environment, political tradition, education and economic development. ${ }^{5}$ The findings are broadly consistent with our main hypothesis $\mathrm{H} 1$ and not supportive of the alternative hypothesis H1a. We argue earlier that the MNC influences its institutional environment over time via three major effects: regulatory pressure effect, demonstration effect, and professionalization effect. While it is difficult to provide precise, direct tests of

5 To check for other institutional control variables, instead of the political and legal variables, we also used a variable that denotes the religious orientation of the country - the percentage of population that follow Protestantism. Religion appears to be a dominant influence on the institutional environment of countries, showing significant correlation with our legal and political variables. Our results are robust to such specification, showing that countries with past FDI exhibit lower rate of corruption, after controlling for religion. The coefficient on FDI is -0.385 , significant at 1 percent level. Also countries with dominant protestant influence display lower incidence of corruption. In addition, we considered a much broader measure of institutional development (instead of the political and legal variables we have) from Kaufmann et al. (1999). This measure reflects the institutional quality, based on measures of voice and accountability, political stability and absence of violence, government effectiveness, regulatory burden, law and order, and freedom from graft. The results show robust negative relation between FDI and corruption. The coefficient estimate is -0.139 which is significant at 10 percent level. The results using religious orientation or institutional development as controls are not reported in the tables owing to page constraint. They will be made available to readers upon request. 
these three effects, we attempt to shed more light on these avenues of influence by examining the moderating role of past FDI on the known effects of two variables on corruption: Culture and Education.

\section{Culture, education and corruption: the moderating effects of FDI}

In this section, we interact the FDI variable with two sets of variables, Culture and Education. The objectives of this exercise are twofold. First, evidence that FDI presence moderates the negative effects of culture, or it strengthens the positive effects of education on corruption would be suggestive of the effects of FDI in play. Second, examining interaction (rather than direct) effects also addresses the potential endogeneity problem we are cognizant of. In the previous section, we regress corruption in 2000s on lagged values of FDI, the lagged values going as far back as 30 years. The fact that the FDI values are not contemporaneous with the corruption data minimizes the concerns on reverse causality. However, it can be argued that past FDI is made in anticipation of the institutional environment in the future so much so that prediction of low corruption in the future attracts more FDI today. One effective way of addressing such endogeneity is to focus on the marginal effect of FDI on the effect of a known variable, such as culture, on corruption. The literature indicates that some cultures, as country effects, breed in corruption. We find earlier that education as a social investment deters corruption. If we find that marginally, the known negative effects of culture is moderated and the known positive effects of education is strengthened by the presence of FDI, then we can say that we have a clearer indicator of causality running from FDI to corruption.

Using Hofstede’s measures of national culture, Husted (1999) identifies power distance, uncertainty avoidance and masculinity to have significant impact on national corruption. Kimbro (2002) reports power distance and individualism as related to corruption after controlling for legal and monitoring variables the way we do. It appears that the consensus is that individualism and power distance are the cultural traits that are associated with corruption; collectivistic cultures and cultures with high power distance gravitate towards high prevalence of corruption. If FDI has the catalyst role through the three effects, it would moderate the harmful effects of culture on corruption. 
Columns (I) through (IV) of Table 4 examine the interaction between power distance and FDI. The results show that, consistent with previous research (see, for examples, Husted (1999), Triandis et al. (2001)), high power-distance countries tend to have high prevalence of corruption. More significantly, the effect of high power-distance on corruption is significantly lower in the presence of FDI; the interaction terms between FDI and power-distance are robustly negative and statistically significant at the one per cent level. Columns (V) through (VIII) provide similar results on the interaction of individualism/collectivism and FDI. Though the coefficient is positive, individualism has no discernible direct effect on incidence of corruption. This is consistent with existing, though ambiguous, evidence about individualism in the literature. For example, Husted (1999) finds no direct effect from individualism to corruption, while Kimbro (2002) finds direct effects, once the effect of countries' wealth is controlled for. More importantly, the effects of individualism/collectivism on corruption are significantly lower in the presence of FDI. ${ }^{6}$

Our analysis in the previous section reveals that one of the critical variables that explain the variations in the prevalence of corruption is education. It can be argued that, via the professionalization effect, FDI presence complements education in transforming the institutional environment of countries. Columns (IX) through (XI) report the results. For education we use the average yearly secondary school enrollment, averaged over 1970 though $2000 .^{7}$ The use of decade averages over 1970s, 1980s and 1990s does not change the results. Consistent with our earlier results, education has positive, though moderate, direct effects on corruption. The coefficients on the education variable are negative and significant at ten per cent level. Consistent with our conjecture, the positive effects of education on corruption are significantly larger in the presence of FDI; the interaction terms between education and FDI are robustly negative and statistically significant as one per cent level. The models in Table 4 perform well, explaining

6 For reasons outlined earlier, we focus on the power distance and individualism attributes of national culture. Though not reported for brevity, the results using the other two attributes, masculinity and uncertainty avoidance, provide qualitatively similar evidence. Again for brevity, we use the overall average FDI over the entire period of 1970 through 1997 as the FDI variable. However, the results are robust when we use the decade averages instead.

7 Secondary school enrollment is a standard measure of human capital in the literature of economic growth (e.g. Barro (1991)). 
more than 80 percent of the cross-country variations in corruption, though our sample has significantly shrunk because of missing values.

\section{Robustness tests}

\section{Using alternative measures for the independent variable}

We provide additional sensitivity checks in this section. First, instead of using the actual values of FDI as independent variable, we include group indicator of high or low FDI countries in the regression. We group the countries into three categories based on their rankings of FDI flows, and designate the bottom-third countries as low-FDI countries with a dummy variable value of 0 , and the top-third countries as high-FDI countries with a dummy variable value of 1 . Columns (I) through (IV) of Table 5 show that our main findings are robust to the alternative measure of FDI. For brevity, we report the results using the FDI and Education variables generated based on averages over the period 1970 through 1997. The results are similar if we use values based on decade averages in 1970s, 1980s or 1990s.

\section{Instrumental variables methodology}

Our findings are based on regressing corruption in 2000s on lagged values of FDI, the lagged values going as far back as 30 years. The fact that the FDI values are not contemporaneous with the corruption data minimizes the concerns one may have about the possibility of reverse causality. However, it could still be argued that past FDI is made based on predictions about the institutional environment in the future such that a forecast of low corruption in the future attracts more FDI today. The robust findings on the channels through which past FDI moderates the harmful effects of culture and strengthens the beneficial effects of education, shown in the previous section, go a long way in allaying our concerns on reverse causality.

An alternative approach to address the endogeneity issue would be to use instruments that disentangle the link between FDI and corruption. We estimate the basic models using the instrumental variables methodology, where we attempt to relate the exogenous component of FDI to corruption. The ideal instruments are variables that might affect corruption but less likely to be affected by it. The most 
difficult task in this setting, however, is the identification of appropriate instruments. It is customary in the finance and economics literature to use such institutional variables as legal origin or colonial history. These variables however, are not useful for our case, as both corruption and FDI are driven by the institutional environment. We look for variables that explain FDI but less likely to be related with corruption. The literature provides a menu of FDI determinants, but most variables are institutional. In addition to variables related to the host country investment climate, FDI is facilitated by better infrastructure including communication networks and supply of power. We use two variables of this nature as instruments: (a) per capita electricity power consumption, and (b) telephone lines (per 1,000 people). We examine the effects of the exogenous component of FDI (the component explainable by our instruments) on corruption. Columns (V) through (VIII) of Table 5 present the instrumental variables (IV) results. Column (V) confirm the major findings from Table 4 that corruption is lower in countries with high past FDI predicted by the instruments. Columns (VI) through (VIII) confirm the main results that FDI moderates the harmful effects of culture and strengthens the positive effects of education. ${ }^{8}$

\section{Change in corruption as a dependent variable}

To address the concern on causality further, we also examine the relation between past FDI and changes (rather than levels) in the corruption measures. Based on the data, we compute the difference between the average corruption level over 2000 through 2004 and the average corruption index between 1995 and 1999, and examine whether the change in the index levels is related to past FDI flows as hypothesized. The results, shown in Table 6, confirm the main results so far. The change in corruption is inversely related to past FDI. In addition, FDI appears to moderate the harmful effects of culture and

8 We follow a two-step procedure where we predict the level of FDI using our two instruments in the first step, and use the predicted FDI values and other predetermined variables to explain variations in corruption. The test for the validity of the instruments using GMM estimation does not support the hypothesis. However, in this test, the set of instruments include both the two instrumental variables we specified and the six exogenous explanatory variables in the model; since, with only two instruments, the model will be under-identified. Nevertheless, this result reflects the difficulty of finding good instruments in our context and suggests that the readers should interpret our instrumental variables results with this limitation in mind. 
strengthens the positive effects of education, as the interaction terms between past FDI and our proxies of culture and education are significantly negative. $^{9}$

\section{Summary and conclusions}

Most empirical research so far examines how the institutional environment of corruption shapes the behavior of MNCs. In this study, we highlight the other side of the picture: how the presence of MNC may shape the institutional environment of corruption over time. We recognize that, in order to strive for external legitimacy, the MNC needs to adapt to its institutional context. Most FDI represents flows from developed countries, where there is generally less corruption. The behavior of MNC in host country is constrained by the regulatory pressure from home country and the international business community (e.g. U.S. Foreign Corrupt Practices Act and OECD Convention on Combating Bribery of Foreign Public Officials in International Business Transactions). In dealing with a foreign business party, the local government officials are constrained somewhat in their bribery acts; it cannot be just business as usual. Over time, together with the demonstration and the professionalization effects, local government officials and business people may model themselves after the MNCs and modify their traditional business practices. They may want to enhance legitimacy within the global business community, raise the country’s international reputation, and attract more business into their country.

We empirically examine our propositions based on an extensive data on FDI and corruption around the world, for a large sample of countries, over the last 30 years. First, consistent with our thesis, we find that current corruption level is significantly lower in countries with high FDI flows in the past. This is true whether we use FDI in 1970s, 1980s or 1990s. Second, we find strong evidence that the harmful effects of culture on corruption are lower and the beneficial effects of education on corruption are higher in countries with higher FDI in the past. Our results are robust to omitted variables bias as we

9 In this study, we do not use the change of corruption level as our main dependent variable. Transparency International computes the Corruption Perception Index as a composite of a number of independent surveys. As explained in Robertson and Watson (2004, p. 390), the sources used differ from year to year. Hence, the CPI is suitable for cross-sectional comparisons but unsuitable for longitudinal comparisons. To alleviate the concern of varying sources over time, we use the average corruption levels of two broad periods to compute the difference. Nevertheless, the readers should interpret the findings with such limitation in mind. 
control for a host of host-country characteristics, including the level of economic development, political tradition, education, culture, legal system, religious orientation and institutional development.

We use multiple ways to alleviate the potential concerns of reverse causality. Firstly, we regress corruption in 2000s on lagged values of FDI, the lagged values going as far back as 30 years. Secondly, we explore the interaction effects between FDI and variables such as culture and education. Thirdly, we employ the instrumental variables methodology, using two instrumental variables, communication network and supply of power, to relate the exogenous component of FDI to corruption. Fourthly, we regress changes (rather than levels) in the corruption measures on past FDI. The robust results give us confidence that there is a causal effect flowing from FDI to corruption.

Our findings confirm the fruitfulness of studying the potential impact of MNCs on the organizational patterns within a country. As contended by Westney (1993), MNC subsidiaries in some countries can play a major role in establishing building blocks of organizations. The introduction of new modes of business practice in MNC subsidiaries can challenge the legitimacy of existing patterns and stimulate debates on better business practices, initiating a “de-institutionalization” process.

Certainly, it would be naïve to think that the influence of MNCs on its institutional environment is always good. There are plenty of anecdotal evidences that MNCs sometimes bring in undesirable influences. However, in the area of corruption, our empirical findings show that the average effect is positive: the presence of FDI could help reduce the corruption level of a host country over time. It enables the MNC to point out to the host government and its people another potential benefit of opening its doors to foreign direct investment. Such a dynamic perspective provides a glimmer of hope to host countries where corruption is widely prevalent. 


\section{References}

Ades, A. and Di Tella, R. (1994) 'Competition and Corruption', Institute of Economics and Statistics Discussion Paper 169, University of Oxford.

Aitken, B. J. and Harrison, A.E. (1999) 'Do Domestic Firms Benefit from Direct Foreign Investment? Evidence from Venezuela’, American Economic Review 89: 605-18.

Barro, R. (1991) 'Economic Growth in A Cross-Section of Countries', Quarterly Journal of Economics CVI: $407-444$.

- (1996) Determinants of Economic Growth: A Cross Country Empirical Study, Cambridge, MA: National Bureau of Economic Research, NBER working paper 5698.

Blomstrom, M. and Kokko, A. (1998) 'Multinational Corporations and Spillovers', Journal of Economic Surveys 12: 247-77.

Dacin, T., Ventresca, M. and Beal, B. (1999) 'The Embeddedness of Organizations: Dialogue \& Directions', Journal of Management 25: 317-356.

Davis, P. S., Desai, A. B. and Francis, J. D. (2000) ' Mode of International Entry: An Isomorphism Perspective’, Journal of International Business Studies 31(2): 239-258.

Djankov, S. D., La Porta, R., Lopez-de-Silanes, F., Shleifer, A. (2003) 'Courts', Quarterly Journal of Economics 118, 453-517.

DiMaggio, P. and Powell, W. (1983) 'The Iron Cage Revisited: Institutional Isomorphism and Collective Rationality in Organizational Fields', American Sociological Review 48 (2): 147-160.

Doh, J., Rodriguez, P., Uhlenbruck, K., Collins, J. and Eden, L. (2003) 'Coping with Corruption in Foreign Markets’, Academy of Management Executive 17 (3): 114-127.

Eden, L., Levitas, E. and Martinez, R. (1997) 'The Production, Transfer, and Spillover Technology', Small Business Economics 9 (1), February: 53-66.

Globerman, S. (1979) 'Foreign Direct Investment and 'Spillover' Efficiency Benefits in Canadian Manufacturing Industries', Canadian Journal of Economics 12: 42-56.

Glynn, M. A. and Abzug, R. (2002) 'Institutional Identity: Symbolic Isomorphism and Organizational Names', Academy of Management Journal 45: 267-280.

Görg, H. and Strobl, E. (2001) 'Multinational Companies and Productivity Spillovers: A Meta-Analysis', The Economic Journal 111: 723-39. 
Haddad, M. and Harrison, A. (1993) 'Are There Positive Spillovers from Direct Foreign Investment?: Evidence from Panel Data for Morocco’, Journal of Development Economics 42: 51-74.

Henisz, W. J., (2000) 'The Institutional Environment of Economic Growth,' Economics and Politics, 12, $1-31$.

Hofstede, G. (2001) Culture’s Consequences, 2nd Edition, London: Sage Publications.

Husted B. (1999) 'Wealth, Culture and Corruption', Journal of International Business Studies 30 (2): 339360.

Jaggers, K., Marshall, M.G., (2000) 'Polity IV Project,' Working Paper, Center for International Development and Conflict Management, University of Maryland.

Kaufmann, D., Kraay, A., and Zoido_Lobatón, P. (1999) 'Governance Matters’, World Bank Research Paper No. 2196.

Kimbro, M. (2002) 'A Cross-Country Empirical Investigation of Corruption and Its Relationship to Economic, Cultural, and Monitoring Institutions: An Examination of the Role of Accounting and Financial Statements Quality’, Journal of Accounting, Auditing \& Finance 17:325-351.

Knack, S. and Keefer, P. (1995) 'Institutions and Economic Performance: Cross-Country Tests Using Alternative Institutional Measures’, Economics and Politics 7 (no. 3): 207-27.

Knack, S. and Keefer, P. (1997) 'Does Social Capital Have an Economic Payoff, a Cross-Country Investigation', Quarterly Journal of Economics 112:1251-1288.

Kostova, T. and Roth, K. (2002) 'Adoption of an Organizational Practice by Subsidiaries of Multinational Corporations: Institutional and Relational Effects’, Academy of Management Journal 45: 215-233.

Lambsdorff, J. (1999) 'Corruption in Empirical Research: A Review', Transparency International Working Paper, Berlin, Germany.

La Porta, R.F., Lo'pez de Silanes, Shleifer, A. and Vishny, R. (1997) 'Trust in Large Organizations', American Economic Review Papers and Proceedings LXXXVII (May): 333-38.

Liu, X., Siler, P., Wang, C. and Wei, Y. (2000) 'Productivity Spillovers from Foreign Direct Investment: Evidence from UK Industry Level Panel Data’, Journal of International Business Studies 31: 407-25.

Macrae, John. (1982) 'Underdevelopment and the Economics of Corruption: A Game Theory Approach', World Development 10 (8): 677-87.

Mauro, P. (1995) ‘Corruption and Growth’, Quarterly Journal of Economics 110: 681-712. 
Mauro, P. (1997) 'The Effects of Corruption on Growth Investment, and Government Expenditure: A Cross-Country Analysis', in K. A. Elliott (ed) Corruption and the Global Economy.

Oliver, C. (1997) 'Sustainable Competitive Advantage: Combining Institutional and Resource-Based Views', Strategic Management Journal 18 (9): 697-713.

Ramirez, A. and Kwok, C. (2006) 'Multinationality as a Moderator of National Institutions: The Case of Culture and Capital Structure Decisions,' CIBER Working Paper, University of South Carolina.

Rao, A. N., Pearce, J. L., Xin, K. (2005) 'Governments, Reciprocal Exchange and Trust among Business Associates,' Journal of International Business Studies 36, 104-118.

Robertson, C. J., and Watson, A. (2004) 'Corruption and Change: The Impact of Foreign Direct Investment', Strategic Management Journal 25: 385-396.

Rodriguez, P., Uhlenbruck, K. and Eden, L. (2005) 'Government Corruption and the Entry Strategies of Multinationals', Academy of Management Review 30:383-396.

Rose-Ackerman, S. (1975) 'The Economics of Corruption’, Journal of Public Economics IV:187-203.

Rose-Ackerman, S. (1999) Corruption and Government: Causes, Consequences, and Reform, London: Cambridge University Press.

Shleifer, A. and Vishny, R. (1993) ‘Corruption’, Quarterly Journal of Economics 108: 599-617.

Triandis, H.C., Carnevale P., Gelfand, M., Robert C., Wasti, A., Probst, T., Kashima, E., Dragonas, T., Chan, D., Chen, X., Kim, U., Drue, C., Vliert, E., Iwao, S., Ohibuchi, K., Schmitz, P. (2001) 'Culture and Deception in Negotiations: A Multilevel Analysis', International Journal of Cross Cultural Management 1, 73-90.

Transparency International (2001) Corruption Perceptions Index 2001, Berlin: Transparency International.

Wei, S.1997. Why is Corruption So Much More Taxing Than Tax? Arbitrariness kills, Cambridge, MA: National Bureau of Economic Research, NBER working paper 6255.

Westney, D.E. (1993) 'Institutionalization Theory and the Multinational Corporation', in S. Ghoshal and D.E. Westney (Eds) Organization Theory and the Multinational Corporation: 53-75, New York: St. Martin's Press.

World Bank (2000) World Development Report: Attacking Poverty, New York: Oxford University Press. World Bank (1999) World Development Indicators. World Bank: Washington DC. 
Figure 1: MNC as an Agent of Change for Host-Country Institutions

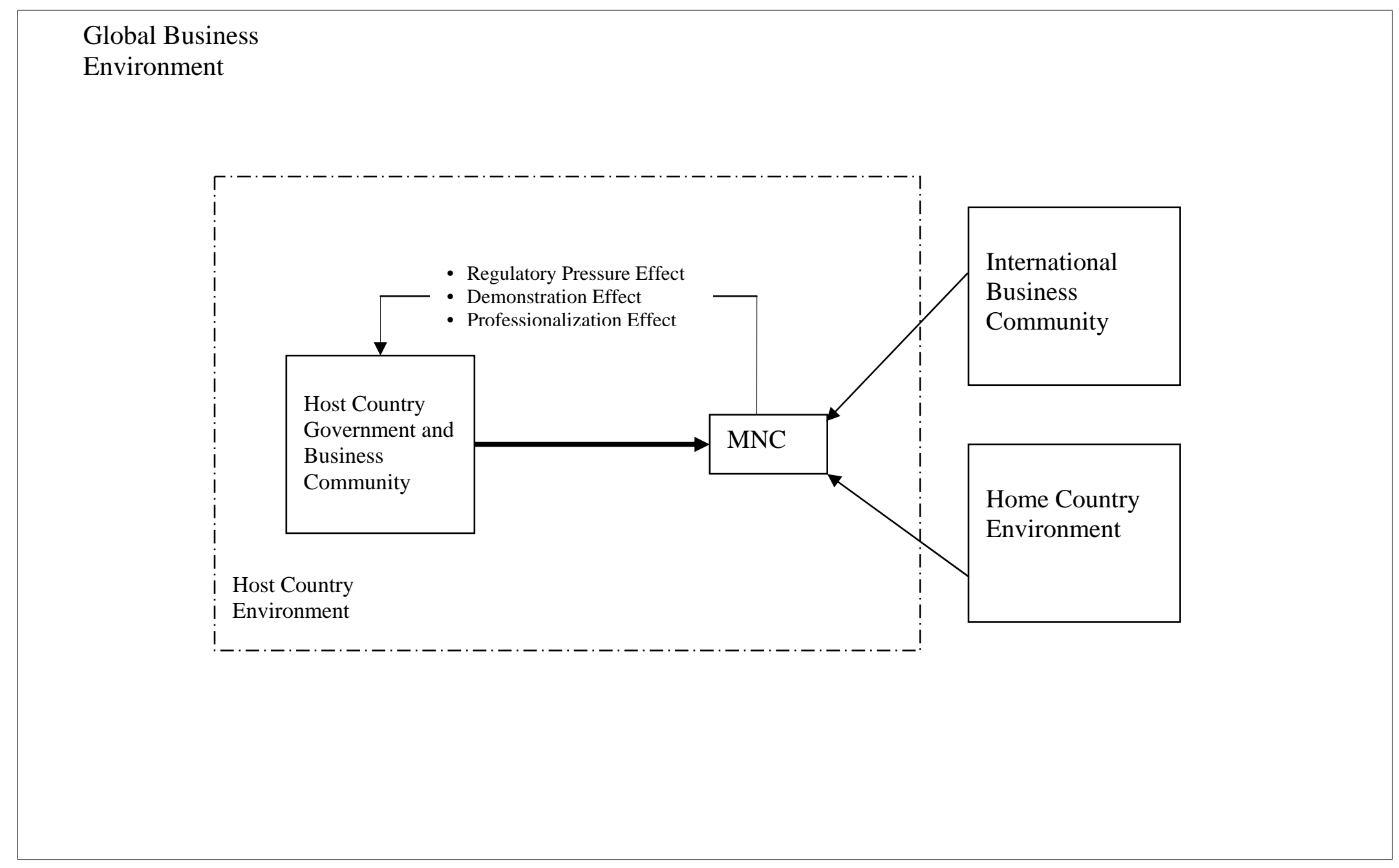


Table 1: Summary Statistics

\begin{tabular}{|c|c|c|c|c|c|}
\hline Variable & Mean & Std Dev & Minimum & Maximum & $\mathbf{N}$ \\
\hline \multicolumn{6}{|l|}{ Dependent Variables: } \\
\hline Corruption 2000-04 & 5.634 & 2.313 & 0.220 & 8.900 & 120 \\
\hline \multicolumn{6}{|l|}{ Independent Variables: } \\
\hline $\begin{array}{l}\text { FDI to GDP in } 1970 \text { s } \\
\text { FDI to GDP in } 1980 \text { s } \\
\text { FDI to GDP in } 1990 \text { s } \\
\text { FDI to GDP } 1970-1997\end{array}$ & $\begin{array}{l}0.933 \\
1.089 \\
2.128 \\
1.488\end{array}$ & $\begin{array}{l}1.318 \\
2.089 \\
4.057 \\
2.204\end{array}$ & $\begin{array}{l}-1.844 \\
-4.206 \\
-11.028 \\
-4.365\end{array}$ & $\begin{array}{l}5.838 \\
14.838 \\
37.284 \\
14.191\end{array}$ & $\begin{array}{l}113 \\
136 \\
140 \\
142\end{array}$ \\
\hline \multicolumn{6}{|l|}{ Control Variables: } \\
\hline Per Capita GDP & 8.291 & 1.123 & 6.064 & 10.164 & 133 \\
\hline $\begin{array}{l}\text { Education in } 1970 \mathrm{~s} \\
\text { Education in } 1980 \mathrm{~s}\end{array}$ & $\begin{array}{l}36.846 \\
47.376\end{array}$ & $\begin{array}{l}27.741 \\
30.237\end{array}$ & $\begin{array}{l}1.000 \\
3.460\end{array}$ & $\begin{array}{c}94.667 \\
107.679\end{array}$ & $\begin{array}{l}128 \\
131\end{array}$ \\
\hline $\begin{array}{l}\text { Education in 1990s } \\
\text { Education in 1970-1997 }\end{array}$ & $\begin{array}{l}55.001 \\
44.408\end{array}$ & $\begin{array}{l}33.795 \\
29.482\end{array}$ & $\begin{array}{l}5.257 \\
1.171\end{array}$ & $\begin{array}{l}129.966 \\
104.442\end{array}$ & $\begin{array}{l}161 \\
130 \\
143\end{array}$ \\
\hline $\begin{array}{l}\text { Democracy } \\
\text { Political Constraint }\end{array}$ & $\begin{array}{l}5.051 \\
0.348\end{array}$ & $\begin{array}{l}3.775 \\
0.324\end{array}$ & $\begin{array}{l}0 \\
0\end{array}$ & $\begin{array}{l}10.000 \\
0.893\end{array}$ & $\begin{array}{c}85 \\
133\end{array}$ \\
\hline Rule of Law & 6.907 & 2.445 & 1.670 & 10.000 & 76 \\
\hline Legal Formalism & 3.549 & 1.015 & 1.414 & 5.907 & 94 \\
\hline \multicolumn{6}{|l|}{ Culture } \\
\hline Power Distance & 56.41 & 21.48 & 11.00 & 104.00 & 56 \\
\hline Individualism/Collectivism & 43.50 & 25.20 & 6.00 & 91.00 & 56 \\
\hline \multicolumn{6}{|l|}{ Instrumental Variables: } \\
\hline $\begin{array}{l}\text { Telephone Lines } \\
\text { Electricity Consumption } \\
\text { (kwh per capita) }\end{array}$ & $\begin{array}{c}85.85 \\
7.2 \mathrm{E} 10\end{array}$ & $\begin{array}{l}123.44 \\
2.8 \mathrm{E} 11\end{array}$ & $\begin{array}{c}0.65 \\
2.6 \mathrm{E} 7\end{array}$ & $\begin{array}{l}594.81 \\
2.7 \mathrm{E} 12\end{array}$ & $\begin{array}{l}134 \\
104\end{array}$ \\
\hline
\end{tabular}


Table 2: Correlation Matrix (figures in parentheses are p values)

\begin{tabular}{|c|c|c|c|c|c|c|c|c|c|c|c|c|c|c|}
\hline & Corruption & $\begin{array}{l}\text { Per capita } \\
\text { GDP }\end{array}$ & $\begin{array}{l}\text { FDI in } \\
1970 \text { s }\end{array}$ & $\begin{array}{l}\text { FDI in } \\
1980 \mathrm{~s}\end{array}$ & $\begin{array}{l}\text { FDI in } \\
1990 \mathrm{~s}\end{array}$ & $\begin{array}{c}\text { FDI } \\
1970- \\
1997\end{array}$ & $\begin{array}{l}\text { Education } \\
\text { in 1970s }\end{array}$ & $\begin{array}{l}\text { Education } \\
\text { in 1980s }\end{array}$ & $\begin{array}{l}\text { Education } \\
\text { in } 1990 \text { s }\end{array}$ & $\begin{array}{c}\text { Education } \\
\text { in 1970- } \\
1997\end{array}$ & $\begin{array}{c}\text { Power } \\
\text { Distance }\end{array}$ & $\begin{array}{l}\text { Individualism } \\
\text { Collectivism }\end{array}$ & Democracy & $\begin{array}{c}\text { Political } \\
\text { Constraint }\end{array}$ \\
\hline Per Capita GDP & $\begin{array}{c}-0.835 \\
(0.0001)\end{array}$ & & & & & & & & & & & & & \\
\hline FDI in 1970s & $\begin{array}{l}-0.1154 \\
(0.141)\end{array}$ & $\begin{array}{c}0.125 \\
(0.207)\end{array}$ & & & & & & & & & & & & \\
\hline FDI in 1980s & $\begin{array}{l}-0.285 \\
(0.003)\end{array}$ & $\begin{array}{c}0.208 \\
(0.022)\end{array}$ & $\begin{array}{r}0.464 \\
(<.0001)\end{array}$ & & & & & & & & & & & \\
\hline FDI in 1990s & $\begin{array}{l}-0.174 \\
(0.076)\end{array}$ & $\begin{array}{c}0.109 \\
(0.223)\end{array}$ & $\begin{array}{c}0.078 \\
(0.409)\end{array}$ & $\begin{array}{c}0.419 \\
(<.0001)\end{array}$ & & & & & & & & & & \\
\hline FDI in 1970-1997 & $\begin{array}{l}-0.208 \\
(0.032)\end{array}$ & $\begin{array}{c}0.119 \\
(0.180)\end{array}$ & $\begin{array}{c}0.405 \\
(<.0001)\end{array}$ & $\begin{array}{c}0.761 \\
(<.0001)\end{array}$ & $\begin{array}{c}0.867 \\
(<.0001)\end{array}$ & & & & & & & & & \\
\hline Education in 1970s & $\begin{array}{c}-0.771 \\
(0.0001)\end{array}$ & $\begin{array}{c}0.889 \\
(<.0001)\end{array}$ & $\begin{array}{c}0.086 \\
(0.386)\end{array}$ & $\begin{array}{c}0.088 \\
(0.343)\end{array}$ & $\begin{array}{c}0.019 \\
(0.839)\end{array}$ & $\begin{array}{c}0.022 \\
(0.817)\end{array}$ & & & & & & & & \\
\hline Education in 1980s & $\begin{array}{c}-0.745 \\
(0.0001)\end{array}$ & $\begin{array}{c}0.834 \\
(<.0001)\end{array}$ & $\begin{array}{c}0.775 \\
(<.0001)\end{array}$ & $\begin{array}{c}0.054 \\
(0.557)\end{array}$ & $\begin{array}{c}0.108 \\
(0.233)\end{array}$ & $\begin{array}{c}0.069 \\
(0.439)\end{array}$ & $\begin{array}{c}0.954 \\
(<.0001)\end{array}$ & & & & & & & \\
\hline Education in in 1990s & $\begin{array}{c}-0.799 \\
(0.0001)\end{array}$ & $\begin{array}{c}0.881 \\
(<.0001)\end{array}$ & $\begin{array}{c}0.089 \\
(0.371)\end{array}$ & $\begin{array}{c}0.087 \\
(0.347)\end{array}$ & $\begin{array}{c}0.079 \\
(0.388)\end{array}$ & $\begin{array}{c}0.027 \\
(0.766)\end{array}$ & $\begin{array}{c}0.923 \\
(<.0001)\end{array}$ & $\begin{array}{c}0.951 \\
(<.0001)\end{array}$ & & & & & & \\
\hline $\begin{array}{l}\text { Education in 1970- } \\
1997\end{array}$ & $\begin{array}{c}-0.746 \\
(0.0001)\end{array}$ & $\begin{array}{c}0.824 \\
(<.0001)\end{array}$ & $\begin{array}{c}0.120 \\
(0.208)\end{array}$ & $\begin{array}{c}0.091 \\
(0.303)\end{array}$ & $\begin{array}{l}-0.026 \\
(0.762)\end{array}$ & $\begin{array}{l}-0.019 \\
(0.818)\end{array}$ & $\begin{array}{c}0.964 \\
(<.0001)\end{array}$ & $\begin{array}{c}0.989 \\
(<.0001)\end{array}$ & $\begin{array}{c}0.975 \\
(<.0001)\end{array}$ & & & & & \\
\hline Power Distance & $\begin{array}{c}0.682 \\
(<.0001)\end{array}$ & $\begin{array}{c}-0.616 \\
(<.0001)\end{array}$ & $\begin{array}{l}-0.002 \\
(0.984)\end{array}$ & $\begin{array}{l}-0.018 \\
(0.904)\end{array}$ & $\begin{array}{l}-0.043 \\
(0.765)\end{array}$ & $\begin{array}{l}-0.004 \\
(0.977)\end{array}$ & $\begin{array}{c}-0.594 \\
(<.0001)\end{array}$ & $\begin{array}{c}-0.618 \\
(<.0001)\end{array}$ & $\begin{array}{c}-0.627 \\
(<.0001)\end{array}$ & $\begin{array}{l}-0.591 \\
(<.0001)\end{array}$ & & & & \\
\hline $\begin{array}{l}\text { Individualism/Collect } \\
\text { ivism }\end{array}$ & $\begin{array}{c}-0.702 \\
(<.0001)\end{array}$ & $\begin{array}{c}0.742 \\
(<.0001)\end{array}$ & $\begin{array}{l}-0.122 \\
(0.418)\end{array}$ & $\begin{array}{l}-0.030 \\
(0.833)\end{array}$ & $\begin{array}{l}-0.151 \\
(0.295)\end{array}$ & $\begin{array}{l}-0.136 \\
(0.344)\end{array}$ & $\begin{array}{c}0.686 \\
(<.0001)\end{array}$ & $\begin{array}{c}0.666 \\
(<.0001)\end{array}$ & $\begin{array}{c}0.749 \\
(<.0001)\end{array}$ & $\begin{array}{c}0.669 \\
(<.0001)\end{array}$ & $\begin{array}{c}-0.647 \\
(<.0001)\end{array}$ & & & \\
\hline Democracy & $\begin{array}{c}-0.686 \\
(<.0001)\end{array}$ & $\begin{array}{c}0.689 \\
(<.0001)\end{array}$ & $\begin{array}{c}0.104 \\
(0.366)\end{array}$ & $\begin{array}{c}0.061 \\
(0.585)\end{array}$ & $\begin{array}{c}0.071 \\
(0.528)\end{array}$ & $\begin{array}{c}0.091 \\
(0.413)\end{array}$ & $\begin{array}{c}0.709 \\
(<.0001)\end{array}$ & $\begin{array}{c}0.673 \\
(<.0001)\end{array}$ & $\begin{array}{c}0.737 \\
(<.0001)\end{array}$ & $\begin{array}{c}0.704 \\
(<.0001)\end{array}$ & $\begin{array}{c}-0.688 \\
(<.0001)\end{array}$ & $\begin{array}{c}0.721 \\
(<.0001)\end{array}$ & & \\
\hline Political Constraint & $\begin{array}{c}-0.607 \\
(<.0001)\end{array}$ & $\begin{array}{c}0.579 \\
(<.0001)\end{array}$ & $\begin{array}{c}0.103 \\
(0.315)\end{array}$ & $\begin{array}{c}0.075 \\
(0.429)\end{array}$ & $\begin{array}{l}-0.026 \\
(0.776)\end{array}$ & $\begin{array}{l}-0.018 \\
(0.840)\end{array}$ & $\begin{array}{c}0.648 \\
(<.0001)\end{array}$ & $\begin{array}{c}0.596 \\
(<.0001)\end{array}$ & $\begin{array}{c}0.611 \\
(<.0001)\end{array}$ & $\begin{array}{c}0.610 \\
(<.0001)\end{array}$ & $\begin{array}{c}-0.449 \\
(<.0001)\end{array}$ & $\begin{array}{c}0.533 \\
(<.0001)\end{array}$ & $\begin{array}{c}0.825 \\
(<.0001)\end{array}$ & \\
\hline Rule of Law & $\begin{array}{c}-0.801 \\
(<.0001)\end{array}$ & $\begin{array}{c}0.703 \\
(<.0001)\end{array}$ & $\begin{array}{c}0.050 \\
(0.694)\end{array}$ & $\begin{array}{c}0.175 \\
(0.151)\end{array}$ & $\begin{array}{c}0.074 \\
(0.542)\end{array}$ & $\begin{array}{c}0.120 \\
(0.322)\end{array}$ & $\begin{array}{c}0.632 \\
(<.0001)\end{array}$ & $\begin{array}{c}0.571 \\
(<.0001)\end{array}$ & $\begin{array}{c}0.608 \\
(<.0001)\end{array}$ & $\begin{array}{c}0.583 \\
(<.0001)\end{array}$ & $\begin{array}{c}-0.645 \\
(<.0001)\end{array}$ & $\begin{array}{c}0.693 \\
(<.0001)\end{array}$ & $\begin{array}{c}0.524 \\
(<.0001)\end{array}$ & $\begin{array}{c}0.420 \\
(<.0001)\end{array}$ \\
\hline
\end{tabular}


Table 3: FDI and Corruption

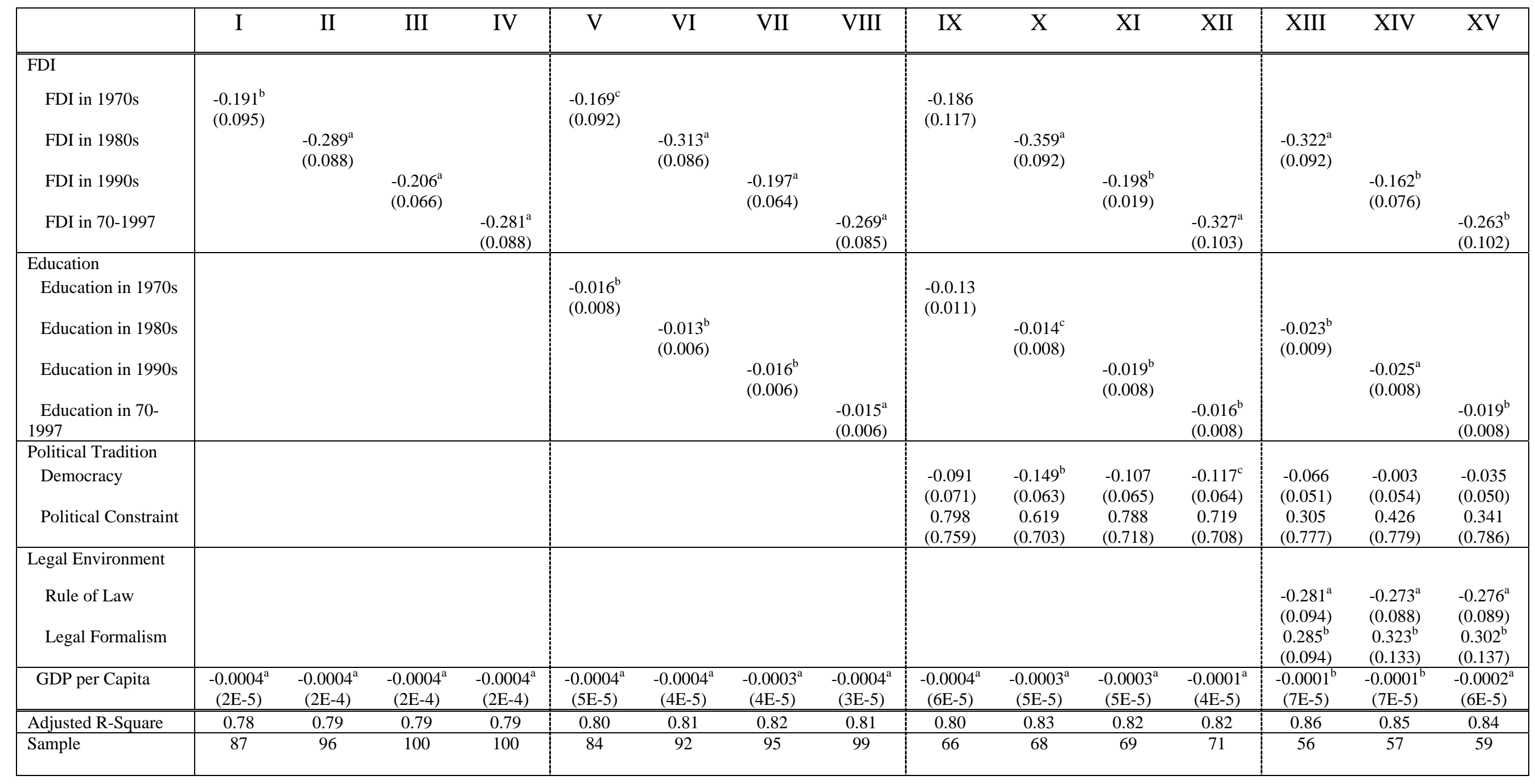

${ }^{\text {a }}$ Significant at 1 per cent; ${ }^{b}$ significant at 5 per cent; ${ }^{c}$ significant at 10 per cent. The figures in parentheses are standard errors. 
Table 4: FDI and Corruption - Channels of Influence

\begin{tabular}{|c|c|c|c|c|c|c|c|c|c|c|c|}
\hline & I & II & III & IV & V & VI & VII & VIII & IX & X & XI \\
\hline $\begin{array}{l}\text { Culture } \\
\text { Power Distance } \\
\text { Individualism/Collectivism }\end{array}$ & $\begin{array}{l}0.040^{\mathrm{a}} \\
(0.009)\end{array}$ & $\begin{array}{c}0.035^{\mathrm{a}} \\
(0.010)\end{array}$ & $\begin{array}{c}0.036^{\mathrm{a}} \\
(0.011)\end{array}$ & $\begin{array}{c}0.026^{\mathrm{b}} \\
(0.012)\end{array}$ & $\begin{array}{l}0.000 \\
(0.009)\end{array}$ & $\begin{array}{c}0.005 \\
(0.009)\end{array}$ & $\begin{array}{c}0.011 \\
(0.012)\end{array}$ & $\begin{array}{c}0.017 \\
(0.012)\end{array}$ & & & \\
\hline $\begin{array}{l}\text { Education } \\
\quad \text { Education in 70-1997 }\end{array}$ & & $\begin{array}{c}-0.021^{\mathrm{b}} \\
(0.009)\end{array}$ & $\begin{array}{l}-0.024^{\mathrm{b}} \\
(0.010)\end{array}$ & $\begin{array}{c}-0.023^{b} \\
(0.010) \\
\end{array}$ & & $\begin{array}{c}-0.0221^{\mathrm{b}} \\
(0.008 \\
\end{array}$ & $\begin{array}{l}-0.023^{b} \\
(0.010)\end{array}$ & $\begin{array}{l}-0.024^{\mathrm{b}} \\
(0.010) \\
\end{array}$ & $\begin{array}{c}-0.009 \\
(0.006) \\
\end{array}$ & $\begin{array}{l}-0.021^{\mathrm{c}} \\
(0.010)\end{array}$ & $\begin{array}{c}0.021^{\mathrm{c}} \\
(0.010) \\
\end{array}$ \\
\hline $\begin{array}{l}\text { FDI X Power Distance } \\
\text { Interactions } \\
\text { FDI in 1970-1997 X Power } \\
\text { Distance }\end{array}$ & $\begin{array}{l}-0.006^{\mathrm{a}} \\
(0.002)\end{array}$ & $\begin{array}{l}-0.006^{\mathrm{a}} \\
(0.001)\end{array}$ & $\begin{array}{l}-0.006^{\mathrm{a}} \\
(0.002)\end{array}$ & $\begin{array}{l}-0.004^{\mathrm{b}} \\
(0.001)\end{array}$ & & & & & & & \\
\hline $\begin{array}{l}\text { FDI } X \\
\text { Individualism/Collectivism } \\
\text { Interaction } \\
\quad \text { FDI in 70-1997 X } \\
\text { Individualism/Collectivism }\end{array}$ & & & & & $\begin{array}{l}-0.014^{\mathrm{a}} \\
(0.003)\end{array}$ & $\begin{array}{l}-0.013^{\mathrm{a}} \\
(0.003)\end{array}$ & $\begin{array}{l}-0.015^{\mathrm{a}} \\
(0.003)\end{array}$ & $\begin{array}{l}-0.010^{\mathrm{b}} \\
(0.004)\end{array}$ & & & \\
\hline $\begin{array}{l}\text { FDI X Education Interaction } \\
\text { FDI in 70-1997 X Education } \\
\text { in70-1997 }\end{array}$ & & & & & & & & & $\begin{array}{l}-0.006^{\mathrm{a}} \\
(0.002)\end{array}$ & $\begin{array}{l}-0.007^{\mathrm{a}} \\
(0.002)\end{array}$ & $\begin{array}{l}-0.004^{\mathrm{b}} \\
(0.002)\end{array}$ \\
\hline $\begin{array}{l}\text { Political Tradition } \\
\text { Democracy } \\
\text { Political Constraint }\end{array}$ & & & $\begin{array}{c}0.011 \\
(0.091) \\
-0.216 \\
(0.948)\end{array}$ & $\begin{array}{c}0.088 \\
(0.102) \\
-0.175 \\
(0.970)\end{array}$ & & & $\begin{array}{c}-0.033 \\
(0.091) \\
-0.483 \\
(0.979)\end{array}$ & $\begin{array}{c}0.0311 \\
(0.094) \\
-0.194 \\
(0.980)\end{array}$ & & $\begin{array}{l}-0.066 \\
(0.085) \\
-0.305 \\
(0.996)\end{array}$ & $\begin{array}{c}0.040 \\
(0.099) \\
-0.128 \\
(1.005)\end{array}$ \\
\hline $\begin{array}{l}\text { Legal Environment } \\
\text { Rule of Law } \\
\text { Legal Formalism }\end{array}$ & & & & $\begin{array}{c}-0.195 \\
(0.119) \\
0.276 \\
(0.189)\end{array}$ & & & & $\begin{array}{c}-0.238^{\mathrm{b}} \\
(0.116) \\
0.325 \\
(0.213)\end{array}$ & & & $\begin{array}{c}-0.238^{\mathrm{c}} \\
(0.121) \\
0.327 \\
(0.198)\end{array}$ \\
\hline GDP per Capita & $\begin{array}{c}-0.0003^{\mathrm{a}} \\
(4 \mathrm{E}-5)\end{array}$ & $\begin{array}{c}-0.0003^{\mathrm{a}} \\
(5 \mathrm{E}-5)\end{array}$ & $\begin{array}{c}-0.0003^{\mathrm{a}} \\
(5 \mathrm{E}-5)\end{array}$ & $\begin{array}{c}-0.0002^{\mathrm{a}} \\
(7 \mathrm{E}-5)\end{array}$ & $\begin{array}{c}-0.0004^{\mathrm{a}} \\
(5 \mathrm{E}-5)\end{array}$ & $\begin{array}{c}-0.0003^{\mathrm{a}} \\
(5 \mathrm{E}-5)\end{array}$ & $\begin{array}{c}-0.0003^{\mathrm{a}} \\
(6 \mathrm{E}-5)\end{array}$ & $\begin{array}{c}-0.0003^{\mathrm{a}} \\
(7 \mathrm{E}-4)\end{array}$ & $\begin{array}{l}-0.0003^{\mathrm{a}} \\
(3 \mathrm{E}-5)\end{array}$ & $\begin{array}{c}-0.0003^{\mathrm{a}} \\
(6 \mathrm{E}-5)\end{array}$ & $\begin{array}{r}-0.0002^{\mathrm{a}} \\
(7 \mathrm{E}-5)\end{array}$ \\
\hline Adjusted R-Square & 0.83 & 0.85 & 0.83 & 0.84 & 0.83 & 0.84 & 0.82 & 0.84 & 0.83 & 0.81 & 0.83 \\
\hline
\end{tabular}

${ }^{\mathrm{a}}$ Significant at 1 per cent; ${ }^{\mathrm{b}}$ significant at 5 per cent; ${ }^{\mathrm{c}}$ significant at 10 per cent. The figures in parentheses are standard errors. 
Table 5: Robustness Tests

\begin{tabular}{|c|c|c|c|c|c|c|c|c|}
\hline & \multicolumn{4}{|c|}{ FDI as a dummy Variable } & \multicolumn{4}{|c|}{ Instrumental Variables } \\
\hline & $\mathrm{I}$ & II & III & IV & $\mathrm{V}$ & VI & VII & VIII \\
\hline $\begin{array}{l}\text { FDI in 1970-1997 } \\
\text { Culture } \\
\quad \text { Power Distance } \\
\text { Individualism/Collectivism }\end{array}$ & $\begin{array}{l}-0.535^{\mathrm{b}} \\
(0.182)\end{array}$ & $\begin{array}{c}0.026^{\mathrm{b}} \\
(0.012)\end{array}$ & $\begin{array}{l}0.027^{b} \\
(0.013)\end{array}$ & & $\begin{array}{l}-1.221^{\mathrm{a}} \\
(0.342)\end{array}$ & $\begin{array}{c}0.025^{\mathrm{b}} \\
(0.012)\end{array}$ & $\begin{array}{c}0.026^{\mathrm{b}} \\
(0.012)\end{array}$ & \\
\hline Education in 70-1997 & $\begin{array}{l}-0.015^{\mathrm{C}} \\
(0.008)\end{array}$ & $\begin{array}{c}-0.014 \\
(0.010)\end{array}$ & $\begin{array}{l}-0.022^{b} \\
(0.010)\end{array}$ & $\begin{array}{c}-0.013 \\
(0.011)\end{array}$ & $\begin{array}{l}-0.016^{\mathrm{b}} \\
(0.008)\end{array}$ & $\begin{array}{c}-0.017 \\
(0.010)\end{array}$ & $\begin{array}{l}-0.023^{b} \\
(0.010)\end{array}$ & $\begin{array}{c}-0.006 \\
(0.011) \\
\end{array}$ \\
\hline $\begin{array}{l}\text { FDIXPD Interaction } \\
\text { FDI in 1970-1997 X Power } \\
\text { Distance }\end{array}$ & & $\begin{array}{l}-0.011^{\mathrm{b}} \\
(0.004)\end{array}$ & & & & $\begin{array}{c}-0.013 \\
(0.008)\end{array}$ & & \\
\hline $\begin{array}{l}\text { FDI } X \text { IC Interaction } \\
\text { FDI in 70-1997XIC }\end{array}$ & & & $\begin{array}{l}-0.010^{\mathrm{b}} \\
(0.004)\end{array}$ & & & & $\begin{array}{l}-0.014^{\mathrm{b}} \\
(0.005)\end{array}$ & \\
\hline $\begin{array}{l}\text { FDI X Education } \\
\text { FDI in 70-1997 X Education } \\
\text { in 70-1997 }\end{array}$ & & & & $\begin{array}{l}-0.007^{b} \\
(0.003)\end{array}$ & & & & $\begin{array}{l}-0.010^{\mathrm{b}} \\
(0.004)\end{array}$ \\
\hline $\begin{array}{l}\text { Political Tradition } \\
\text { Democracy } \\
\text { Political Constraint }\end{array}$ & $\begin{array}{c}-0.058 \\
(0.072) \\
0.533 \\
(0.775) \\
\end{array}$ & $\begin{array}{c}0.066 \\
(0.099) \\
0.386 \\
(0.939) \\
\end{array}$ & $\begin{array}{c}0.041 \\
(0.093) \\
0.121 \\
(0.956) \\
\end{array}$ & $\begin{array}{c}0.068 \\
(0.093) \\
0.112 \\
(0.980) \\
\end{array}$ & $\begin{array}{c}0.023 \\
(0.071) \\
0.266 \\
(0.735) \\
\end{array}$ & $\begin{array}{c}0.161 \\
(0.100) \\
0.030 \\
(0.994) \\
\end{array}$ & $\begin{array}{c}0.107 \\
(0.093) \\
-0.016 \\
(0.946) \\
\end{array}$ & $\begin{array}{c}0.121 \\
(0.091) \\
-0.047 \\
(0.969) \\
\end{array}$ \\
\hline $\begin{array}{l}\text { Legal Environment } \\
\text { Rule of Law } \\
\text { Legal Formalism }\end{array}$ & $\begin{array}{c}-0.256^{\mathrm{a}} \\
(0.088) \\
0.316^{\mathrm{b}} \\
(0.133)\end{array}$ & $\begin{array}{c}-0.258^{\mathrm{b}} \\
(0.111) \\
0.307 \\
(0.174)\end{array}$ & $\begin{array}{c}-0.273^{\mathrm{b}} \\
(0.112) \\
0.458^{\mathrm{b}} \\
(0.185)\end{array}$ & $\begin{array}{c}-0.251^{\mathrm{b}} \\
(0.116) \\
0.362^{\mathrm{c}} \\
(0.182)\end{array}$ & $\begin{array}{c}-0.237^{\mathrm{a}} \\
(0.086) \\
0.382^{\mathrm{a}} \\
(0.129)\end{array}$ & $\begin{array}{c}-0.249^{\mathrm{b}} \\
(0.119) \\
0.429^{\mathrm{b}} \\
(0.174)\end{array}$ & $\begin{array}{c}-0.270^{\mathrm{b}} \\
(0.110) \\
0.564^{\mathrm{a}} \\
(0.176)\end{array}$ & $\begin{array}{c}-0.262^{\mathrm{b}} \\
(0.113) \\
0.467^{\mathrm{a}} \\
(0.168)\end{array}$ \\
\hline GDP per Capita & $\begin{array}{c}-0.0002^{\mathrm{a}} \\
(6 \mathrm{E}-5)\end{array}$ & $\begin{array}{c}0.0002^{\mathrm{a}} \\
(7 \mathrm{E}-5)\end{array}$ & $\begin{array}{l}0.0003^{\mathrm{a}} \\
(7 \mathrm{E}-5)\end{array}$ & $\begin{array}{l}0.0002^{\mathrm{a}} \\
(7 \mathrm{E}-5)\end{array}$ & $\begin{array}{c}-0.00008 \\
(6 \mathrm{E}-5)\end{array}$ & $\begin{array}{c}-0.0002^{b} \\
(8 \mathrm{E}-5)\end{array}$ & $\begin{array}{c}-0.0002^{\mathrm{a}} \\
(7 \mathrm{E}-5)\end{array}$ & $\begin{array}{c}-0.0002^{\mathrm{a}} \\
(7 \mathrm{E}-5)\end{array}$ \\
\hline Adjusted R-Square & 0.85 & 0.84 & 0.85 & 0.84 & 0.85 & 0.83 & 0.84 & 0.83 \\
\hline Sample & 59 & 42 & 42 & 42 & 57 & 42 & 42 & 42 \\
\hline
\end{tabular}

${ }^{\text {a }}$ Significant at 1 per cent; ${ }^{\mathrm{b}}$ significant at 5 per cent; ${ }^{\mathrm{c}}$ significant at 10 per cent. The figures in parentheses are standard errors. 
Table 6: FDI and Change of Corruption

\begin{tabular}{|c|c|c|c|c|}
\hline & \multicolumn{4}{|c|}{ Corruption as a Change } \\
\hline & I & II & III & IV \\
\hline $\begin{array}{l}\text { FDI in 1970-1997 } \\
\text { Culture } \\
\text { Power Distance } \\
\text { Individualism/Collectivism }\end{array}$ & $\begin{array}{l}-0.595^{\mathrm{a}} \\
(0.221)\end{array}$ & $\begin{array}{c}0.064^{\mathrm{b}} \\
(0.024)\end{array}$ & $\begin{array}{c}0.051^{\mathrm{c}} \\
(0.026)\end{array}$ & \\
\hline Education in 70-1997 & $\begin{array}{l}-0.043^{\mathrm{a}} \\
(0.017)\end{array}$ & $\begin{array}{l}-0.047^{\mathrm{b}} \\
(0.019)\end{array}$ & $\begin{array}{l}-0.054^{\mathrm{b}} \\
(0.021)\end{array}$ & $\begin{array}{l}-0.040^{\mathrm{C}} \\
(0.021) \\
\end{array}$ \\
\hline $\begin{array}{l}\text { FDIXPD Interaction } \\
\text { FDI in 1970-1997 X Power } \\
\text { Distance }\end{array}$ & & $\begin{array}{l}-0.010^{\mathrm{a}} \\
(0.004)\end{array}$ & & \\
\hline $\begin{array}{l}\text { FDI X IC Interaction } \\
\text { FDI in 70-1997XIC }\end{array}$ & & & $\begin{array}{c}-0.020^{\mathrm{b}} \\
(0.0086)\end{array}$ & \\
\hline $\begin{array}{l}\text { FDI X Education } \\
\text { FDI in 70-1997 X Education } \\
\text { in 70-1997 }\end{array}$ & & & & $\begin{array}{l}-0.011^{\mathrm{b}} \\
(0.005)\end{array}$ \\
\hline $\begin{array}{l}\text { Political Tradition } \\
\text { Democracy } \\
\text { Political Constraint }\end{array}$ & $\begin{array}{c}-0.090 \\
(0.152) \\
0.714 \\
(1.709) \\
\end{array}$ & $\begin{array}{l}0.174 \\
(0.198) \\
-1.703 \\
(2.127) \\
\end{array}$ & $\begin{array}{c}0.025 \\
(0.186) \\
-1.115 \\
(2.121) \\
\end{array}$ & $\begin{array}{l}0.034 \\
(0.193) \\
-1.516 \\
(2.230) \\
\end{array}$ \\
\hline $\begin{array}{l}\text { Legal Environment } \\
\text { Rule of Law } \\
\text { Legal Formalism }\end{array}$ & $\begin{array}{c}-0.631^{\mathrm{a}} \\
(0.175) \\
0.667^{\mathrm{b}} \\
(0.289) \\
\end{array}$ & $\begin{array}{l}-0.401^{\mathrm{c}} \\
(0.231) \\
0.715^{\mathrm{c}} \\
(0.387) \\
\end{array}$ & $\begin{array}{c}-0.549^{\mathrm{b}} \\
(0.227) \\
0.906^{\mathrm{c}} \\
(0.481) \\
\end{array}$ & $\begin{array}{l}-0.485^{\mathrm{b}} \\
(0.237) \\
0.733^{\mathrm{c}} \\
(0.409) \\
\end{array}$ \\
\hline GDP per Capita & $\begin{array}{c}-0.0003^{\mathrm{a}} \\
(1 \mathrm{E}-4) \\
\end{array}$ & $\begin{array}{c}0.0004^{\mathrm{a}} \\
(1 \mathrm{E}-4) \\
\end{array}$ & $\begin{array}{c}0.0005^{\mathrm{a}} \\
(1 \mathrm{E}-4) \\
\end{array}$ & $\begin{array}{r}0.0004^{\mathrm{a}} \\
(1 \mathrm{E}-4) \\
\end{array}$ \\
\hline Adjusted R-Square & 0.86 & 0.86 & 0.85 & 0.84 \\
\hline Sample & 54 & 40 & 40 & 40 \\
\hline
\end{tabular}

${ }^{\text {a }}$ Significant at 1 per cent; ${ }^{\mathrm{b}}$ significant at 5 per cent; ${ }^{\mathrm{c}}$ significant at 10 per cent. The figures in parentheses are standard errors. 


\section{Appendix 1: Variables and Sources}

\begin{tabular}{|c|c|c|}
\hline Variables & Definition & Sources \\
\hline \multicolumn{3}{|l|}{ Dependent Variables: } \\
\hline Corruption & $\begin{array}{l}\text { A measure of the corruption perception. Corruption is defined as abuse of public } \\
\text { office, and the corruption index measures the corruption perception based on } \\
\text { survey of business people and analysts. The measure is rescaled from the original } \\
\text { by taking the difference from } 10 \text {. The values are averages over the period } 2000 \\
\text { through } 2004\end{array}$ & $\begin{array}{l}\text { Source: Transparency International } \\
\text { (various issues) }\end{array}$ \\
\hline \multicolumn{3}{|c|}{ Foreion direct invectment is inflows of inyectment to acruire a lacting management } \\
\hline FDI to GDP ratio (\%) in 70s, 80s, 90s and 1970-1997 & $\begin{array}{l}\text { Foreign direct investment is inflows of investment to acquire a lasting management } \\
\text { interest ( } 10 \text { percent or more of voting stock) in an enterprise operating in an } \\
\text { economy other than that of the investor. It is the sum of equity capital, } \\
\text { reinvestment of earnings, other long-term capital, and short-term capital as shown } \\
\text { in the balance of payments. The values are decade averages over 1970s, 1980s, } \\
\text { 1990s and over the period } 1970 \text { through } 1997 .\end{array}$ & Source: World Bank (1999) \\
\hline Education (in 70s, 80s, 90s, and 1970-1997) & $\begin{array}{l}\text { Gross secondary enrollment ratio is the ratio of total enrollment, regardless of age, } \\
\text { to the population of the age group that officially corresponds to the level of } \\
\text { education shown. It is measured as secondary school enrollment at a fraction of } \\
\text { the age group eligible to the level of education. The values are decade averages } \\
\text { over the } 1970 \text { s, the } 1980 \text { s, the } 1990 \text { s and overall average over the period } 1970 \\
\text { through } 1997 \text {. }\end{array}$ & Source: World Bank (1999) \\
\hline \multicolumn{3}{|l|}{ Culture } \\
\hline Power Distance & $\begin{array}{l}\text { Hofstede's cultural value that reflects the response of people to inequality. It } \\
\text { represents the extent to which the less powerful members of society accept, expect } \\
\text { or prefer injustice. }\end{array}$ & Source: Hofstede (2001) \\
\hline Individualism/Collectivism & $\begin{array}{l}\text { Hofstede's cultural value that reflects the degree to which people in society are } \\
\text { primarily concerned with their own self-interest over that of the collective. }\end{array}$ & Source: Hofstede (2001) \\
\hline \multicolumn{3}{|l|}{ Control Variables } \\
\hline Per capita GDP & The logarithm of average per capita GDP & Source: World Bank (1999) \\
\hline Democracy & $\begin{array}{l}\text { A measure of the degree of democracy in a given country based on: (1) the } \\
\text { competitiveness of political participation; ( } 2 \text { ) the openness and competitiveness of } \\
\text { executive recruitment; and (3) the constraints on the chief executive. The variable } \\
\text { ranges from zero to ten, where higher values equal a higher degree of } \\
\text { institutionalized democracy. This variable is calculated as the average from } 1960 \\
\text { through 2000, or for specific years as needed in the tables. }\end{array}$ & $\begin{array}{l}\text { Source: Jaggers and Marshall } \\
\text { (2000). }\end{array}$ \\
\hline Political Constraints & $\begin{array}{l}\text { A measure of the extent of institutionalized constraints on the decision making of } \\
\text { political actors. The values are averages over } 1970 \text { through } 2000\end{array}$ & Source: Henisz (2000) \\
\hline Rule of Law & $\begin{array}{l}\text { A measure of the prevalence of law and order and is based on the Political Risk } \\
\text { Services Group's International Country Guide (various issues), on a scale of } 0 \text { to } \\
10 .\end{array}$ & Source: Djankov et al. (2003) \\
\hline Legal Formalism & $\begin{array}{l}\text { The index measures substantive and procedural statutory intervention in judicial } \\
\text { cases at lower-level civil trial courts, and is formed by adding up the following } \\
\text { indices: (i) professionals vs. laymen, (ii) written vs. oral elements, (iii) legal } \\
\text { justification, (iv) statutory regulation of evidence, (v) control of superior review, } \\
\text { (vi) engagement formalities, and (vii) independent procedural actions. The index } \\
\text { ranges from } 0 \text { to } 7 \text {, where } 7 \text { means a higher level of control or intervention in } \\
\text { the judicial process. }\end{array}$ & Source: Djankov et al. (2003) \\
\hline \multicolumn{3}{|l|}{ Instrumental Variables } \\
\hline Telephone Lines & $\begin{array}{l}\text { Telephone lines are the total number of fixed lines and mobile phone subscribers } \\
\text { (per 1,000 people). Fixed lines are telephone mainlines connecting a customer's } \\
\text { equipment to the public switched telephone network. Mobile phone subscribers } \\
\text { refer to users of portable telephones subscribing to an automatic public mobile } \\
\text { telephone service using cellular technology that provides access to the public } \\
\text { switched telephone network. The values are averages over } 1970 \text { through } 1997 .\end{array}$ & Source: World Bank (1999) \\
\hline Electricity Consumption & $\begin{array}{l}\text { Electric power consumption measures the production of power plants and } \\
\text { combined heat and power plants, less distribution losses, and own use by heat and } \\
\text { power plants per capita. The value is average over } 1970 \text { through } 1997 .\end{array}$ & Source: World Bank (1999) \\
\hline
\end{tabular}




\section{DAVIDSON INSTITUTE WORKING PAPER SERIES - Most Recent Papers}

The entire Working Paper Series may be downloaded free of charge at: www.wdi.umich.edu

CURRENT AS OF 07/6/07

\begin{tabular}{|c|c|c|}
\hline Publication & Authors & Date \\
\hline $\begin{array}{l}\text { No. 882: The MNC as an Agent of Change for Host-Country Institutions: } \\
\text { FDI \& Corruption }\end{array}$ & $\begin{array}{l}\text { Chuck Kwok and Solomon } \\
\text { Tadesse }\end{array}$ & Sept 2006 \\
\hline $\begin{array}{l}\text { No. 881: The Allocation and Monitoring Role of Capital Markets: } \\
\text { Theory and International Evidence }\end{array}$ & Solomon Tadesse & $\begin{array}{l}\text { March } \\
2003\end{array}$ \\
\hline No. 880: Tunisia: Sources of Real Exchange Rate Fluctuations & Sfia Mohamed Daly & $\begin{array}{l}\text { March } \\
2006\end{array}$ \\
\hline No. 879: Financial Development \& Technology & Solomon Tadesse & June 2007 \\
\hline $\begin{array}{l}\text { No. 878: Consolidation, Scale Economics \& Technological Change in } \\
\text { Japanese Banking }\end{array}$ & Solomon Tadesse & Feb 2005 \\
\hline No. 877: Innovation, Information and Financial Architecture & Solomon Tadesse & June 2007 \\
\hline $\begin{array}{l}\text { No. 876: Corporate Cash Holdings, National Culture, and } \\
\text { Multinationality }\end{array}$ & $\begin{array}{l}\text { Andres Ramirez and Solomon } \\
\text { Tadesse }\end{array}$ & June 2007 \\
\hline $\begin{array}{l}\text { No. 875: The Economic Value of Regulated Disclosure: Evidence from } \\
\text { the Banking Sector }\end{array}$ & Solomon Tadesse & Jan 2006 \\
\hline No. 874:Banking Fragility \& Disclosure: International Evidence & Solomon Tadesse & Sept 2006 \\
\hline $\begin{array}{l}\text { No. 873: The Impact of Outward FDI on Home-Country } \\
\text { Employment in a Low-Cost Transition Economy }\end{array}$ & $\begin{array}{l}\text { Jaan Masso, Urmas Varblane and } \\
\text { Priit Vahter }\end{array}$ & May 2007 \\
\hline $\begin{array}{l}\text { No. 872: Local Distributional Effects of Government Cash Transfers in } \\
\text { Chile }\end{array}$ & $\begin{array}{l}\text { Claudio A. Agostini and Philip } \\
\text { Brown }\end{array}$ & May 2007 \\
\hline $\begin{array}{l}\text { No. 871: How do Workers Fare During Transition?Perceptions of Job } \\
\text { Insecurity among Russian Workers, 1995-2004 }\end{array}$ & $\begin{array}{l}\text { Susan J. Linz and Anastasia } \\
\text { Semykina }\end{array}$ & April 2007 \\
\hline $\begin{array}{l}\text { No. 870: Does Reform Work? An Econometric Examination of the } \\
\text { Reform-Growth Puzzle }\end{array}$ & Ian Babetskii and Nauro Campos & April 2007 \\
\hline No. 869: Perceptions and Behavior: Analyzing Wage Arrears in Russia & $\begin{array}{l}\text { Susan Linz, Anastasia Semykina } \\
\text { and Charles Petrin }\end{array}$ & June 2006 \\
\hline $\begin{array}{l}\text { No. 868: The Endogeneity of Association Agreements and their Impact } \\
\text { on Trade for Eastern Countries: Empirical Evidence for Romania }\end{array}$ & $\begin{array}{l}\text { Christophe Rault, Ana Maria Sova } \\
\text { and Robert Sova }\end{array}$ & April 2007 \\
\hline $\begin{array}{l}\text { No. 867: Institutions \& Entrepreneurship Development in Russia: A } \\
\text { Comparative Perspective }\end{array}$ & $\begin{array}{l}\text { Saul Estrin, Ruta Aidis and } \\
\text { Tomasz Mickiewicz }\end{array}$ & Feb 2007 \\
\hline No. 866: Dutch Disease Scare in Kazakhstan: Is it real? & Balázs Égert and Carol S. Leonard & $\begin{array}{l}\text { March } \\
2007\end{array}$ \\
\hline $\begin{array}{l}\text { No. 865: Minimum Wage and Tax Evasion: Theory } \\
\text { and Evidence }\end{array}$ & Mirco Tonin & Jan 2007 \\
\hline $\begin{array}{l}\text { No. 864: Dynamics of the Financial Wealth of the Institutional Sectors in } \\
\text { Bulgaria: Empirical Studies of the Post-Communist Period }\end{array}$ & $\begin{array}{l}\text { Nikolay Nenovsky and Gergana } \\
\text { Mihaylova }\end{array}$ & $\begin{array}{l}\text { March } \\
2007\end{array}$ \\
\hline $\begin{array}{l}\text { No. 863: Impact of Derivatives Trading on Emerging Capital Markets: A } \\
\text { Note on Expiration Day Effects in India }\end{array}$ & $\begin{array}{l}\text { Sumon Kumar Bhaumik and } \\
\text { Suchismita Bose }\end{array}$ & $\begin{array}{l}\text { March } \\
2007\end{array}$ \\
\hline $\begin{array}{l}\text { No. 862: Short- \& Medium- Term Determinants of Current Account } \\
\text { Balances in Middle East \& North Africa Countries }\end{array}$ & Aleksander Aristovnik & $\begin{array}{l}\text { March } \\
2007\end{array}$ \\
\hline $\begin{array}{l}\text { No. 861: Time-Varying Comovements in Developed and Emerging } \\
\text { European Stock Markets: Evidence from Intraday Data }\end{array}$ & Balázs Égert and Evžen Kočenda & $\begin{array}{l}\text { March } \\
2007\end{array}$ \\
\hline $\begin{array}{l}\text { No: 860: Giving Children a Better Start: Preschool Attendance \& } \\
\text { School-Age Profiles }\end{array}$ & $\begin{array}{l}\text { Sam Berlinski, Sebastian Galiani } \\
\text { and Marco Manacorda }\end{array}$ & Jan 2007 \\
\hline $\begin{array}{l}\text { No. 859: Real Exchange Rates in Small open OECD \& Transition } \\
\text { Economies: Comparing Apples with Oranges? }\end{array}$ & $\begin{array}{l}\text { Balázs Égert, Kirsten } \\
\text { Lommatzsch and Amina } \\
\text { Lahreche-Revil }\end{array}$ & Jan 2007 \\
\hline $\begin{array}{l}\text { No. 858: Is Education the Panacea for Economic Deprivation of } \\
\text { Muslims? Evidence from Wage Earners in India, 1987-2004 }\end{array}$ & $\begin{array}{l}\text { Sumon Kumar Bhaumik and } \\
\text { Manisha Chakrabarty }\end{array}$ & Jan 2007 \\
\hline $\begin{array}{l}\text { No. 857: Human Capital, Economic Growth, and Regional Inequality in } \\
\text { China }\end{array}$ & $\begin{array}{l}\text { Belton Fleisher, Haizheng Li and } \\
\text { Min Qiang Zhao }\end{array}$ & Jan 2007 \\
\hline
\end{tabular}

